\title{
ОТВОД СУДЬИ В ГРАЖДАНСКОМ ПРОЦЕССЕ. РЕАЛЬНОСТЬ ИЛИ ФИКЦИЯ?
}

\begin{abstract}
Аннотация: В статье рассматривается проблема реализации права участников судебного процесса на отвод судьи в гражданском процессе. Анализируется современное российское законодательство, регулирующее отношения в сфере реализации права гражданина на судебную защиту его прав и свобод, и на рассмотрение его дела справедливым и беспристрастным судом. Институт отвода судьи рассмотрен с позиции функциональной направленности, не как формальная норма, но как правовое средство для правильного и своевременного рассмотрения и разрешения гражданских дел. Речь идет о нелогичности и неэффективности данного института в современном гражданско-процессуальном поле, и о необходимости изменения законодательства на основе общепризнанных мировых принципов права.
\end{abstract}

Ключевые слова: Юриспруденщия, Гражданский процесс, Отвод, Основания отвода, Законодательство, Римское право, Объективность, Справедливость, Беспристрастность, Конституциия

Российской Федерации каждому гражданину гарантируется судебная защита его прав и свобод, а также провозглашается независимость судей и подчинение их только Конституции РФ и федеральным законам. Последний конституционный принцип продублирован на отраслевом уровне в ст. 8 ГПК РФ. Реализация названных принципов способствует решению, пожалуй, главной задачи гражданского судопроизводства - правильному и своевременному рассмотрению и разрешению гражданских дел и, как следствие, вынесению законных и обоснованных судебных постановлений.

Поскольку важнейшими факторами при реализации данных принципов гражданского процесса являются объективность и беспристрастность судей, возникает вопрос: как добиться объективности и беспристрастности от суда, на сегодняшний день в отсутствие института народных заседателей, когда судья первой инстанции рассматривает гражданские дела единолично.

Казалось бы, при таких обстоятельствах обеспечению справедливого правосудия может и должен способствовать институт отвода судей. ${ }^{1}$

Заявления об отводе судей, которые практически ежедневно заявляются в российских судах лицами, участвующими в деле, всякий раз наталкиваются на нелогичный и неэффективный механизм реализации их права на данный отвод.

Давайте рассмотрим нормы гражданского процессуального закона.

В соответствии с ч. $1 \mathrm{~cm} .19$ Гражданского проиессуального кодекса РФ отвод может быть заявлен лииами, участвующими в деле.

${ }^{1}$ Добровольский А.А. Исковая форма защиты права. М., 1965, С 180.
На основании ч. 2 cm. 19 Гражданского проиессуального кодекса РФ отвод должен быть мотивирован и заявлен до начала рассмотрения дела по существу. Заявление отвода в ходе дальнейтего рассмотрения дела допускается только в случае, если основание для отвода стало известно лииу, заявляющему отвод, после начала рассмотрения дела по существу.

Основания для отвода судьи перечислены в $\mathrm{cm} .16$ ГПК РФ:

1. Мировой судья, а также судья не может рассматривать дело и подлежит отводу, если он:

1) при предыдущем рассмотрении данного дела участвовал в нем в качестве прокурора, секретаря судебного заседания, представителя, свидетеля, эксперта, спеичиалиста, переводчика;

2) является родственником или свойственником кого-либо из лии, участвуюших в деле, либо их представителей;

3) лично, прямо или косвенно заинтересован в исходе дела либо имеются иные обстоятельства, вызываюшие сомнение в его объективности и беспристрастности.

2. В состав суда, рассматривающего дело, не могут входить лииа, состоящие в родстве между собой.

Статья 20 ГПК РФ определяет порядок разрешения заявления об отводе. Так в абзаце 1 части 2 названной статьи указано, что вопрос об отводе, заявленном судье, рассматривающему дело единолично, разрешается тем же судьей. При рассмотрении дела судом коллегиально вопрос об отводе судьи разрешается этим же составом суда в отсутствие отводимого судьи. При равном количестве голосов, поданных за отвод и против отвода, судья считается отведенным. Вопрос об отводе, заявленном нескольким судьям или всему составу суда, разрешается этим же судом в полном составе простым большинством голосов. 
Вопрос об отводе прокурора, секретаря судебного заседания, эксперта, специилиста, переводчика разрешается судом, рассматривающим дело.

Из приведенных норм очевидно, что на сегодняшний день, воспользоваться данным институтом отвода на практике в гражданском судопроизводстве, когда дело рассматривается судьей единолично, невозможно в силу того, что законодатель оставляет вопрос об отводе судьи, единолично рассматривающего дело, на разрешение того же судьи. Подобный подход к разрешению данного вопроса представляется по мере противоречивым самому назначению института отвода судей, поскольку ставит удовлетворение ходатайства об отводе при наличии обстоятельств, достаточных для этого в силу закона, в зависимость от усмотрения судьи, которому заявлен отвод. ${ }^{2}$

Если следовать логике законодателя, судья, получивший заявление об отводе по причине заинтересованности в исходе дела или наличия обстоятельств, вызывающих сомнения в его объективности и беспристрастности, должен удалиться в совещательную комнату и там решить вопрос о том, действительно ли он беспристрастен и никоим образом не заинтересован в результате рассмотрения дела. Но в такой ситуации вполне логичным выглядит как раз отклонение судьей заявления об отводе. Нелогичным было бы обратное: судья удовлетворяет заявление о своем отводе, согласившись с тем, что он не беспристрастен и по каким-либо причинам заинтересован в результате рассмотрения дела.

Ведь удовлетворив подобное заявление, судья автоматически признает себя несовместимым с занимаемой должностью, так как одним из требований, предъявляемых к судье ст. 3 Закона РФ от 26 июня 1992 г. № 3132-1 «О статусе судей в Российской Федерации» (в ред. от 5 апреля 2005 г.), является недопущение поступков, позволяющих усомниться в его объективности, справедливости и беспристрастности. ${ }^{3}$

Еще с эпохи Древнего Рима известно, что никто не может быть судьей в собственном деле. ${ }^{4}$ Это настолько очевидно, что прямо не отражено ни в одной норме Российского закона.

Хотя в Конституции РФ косвенно данный принцип все же закреплен.

Конституция Российской Федерации гарантирует каждому судебную защиту его прав и свобод на основе состязательности и равноправия сторон, а также в соответствии с принципами независимости судей и под-

${ }^{2}$ Багаутдинов Ф.Н. Актуальные проблемы отвода судьи в современных условиях // Журналроссийского права № 5, май 2009 г., С 9.

3 Заявление и разрешение повторных отводов суду (судье) на стадии судебного разбирательства // Адвокат, № 10, октябрь 2009 г., С 3.

${ }^{4}$ Муромцев С.А., Гражданское право древнего Рима, М., 1883 г. C. 20 . чинения их только Конституции Российской Федерации и федеральному закону (статья 46, часть 1; статья 120 , часть 1 ; статья 123 , часть 3 , Конституции Российской Федерации). Кроме того, статьей 6 ратифицированной Российской Федерацией Конвенции о защите прав человека и основных свобод, являющейся в силу статьи 15 (часть 4) Конституции Российской Федерации составной частью российской правовой системы, закреплено право каждого при определении его гражданских прав и обязанностей на справедливое и публичное разбирательство дела в разумный срок независимым и беспристрастным судом, созданным на основании закона.

Очевидно, что если судья действительно заинтересован в исходе дела либо имеются иные обстоятельства, вызывающие сомнения в его объективности, справедливости и способности рассмотреть дело в соответствии с законом, то он не сможет беспристрастно и объективно разрешить вопрос и о своем отводе.

Более того, сам по себе отказ судьи в удовлетворении заявленного ему отвода, является обстоятельством, вызывающим сомнение в его объективности и беспристрастности. Ведь если судья беспристрастен и не имеет заинтересованности в исходе дела, то почему же не удовлетворить отвод и не передать данное дело на разрешение другому судье?

Бесспорно, что каждый человек, и судья не исключение, не может быть беспристрастным в оценке своих собственных действий. Направление жалобы для разрешения по существу тому лицу, чьи действия обжалуются, делает обжалование бессмысленным.

При рассмотрении отвода самому себе судья перестает быть арбитром, отстраненно оценивающим доводы спорящих перед ним сторон. Он вынужденно совмещает функцию лица, приводящего доводы в защиту правомерности собственных действий, и функцию разрешения поставленного перед ним вопроса. И в этом случае судья не может сохранить объективность и беспристрастность. ${ }^{5}$ Может ли судья сохранить независимость и руководствоваться только Конституцией РФ и федеральными законами, если при заявлении отвода по основаниям, указанным в п. 3 ч. 1 ст. 16 ГПК РФ, речь идет не о легко проверяемых фактах (например: участия судьи в предыдущем рассмотрении дела в качестве свидетеля, эксперта и т.д. или наличия родственных связей), а об оценки собственных действий?

Проблема с реализацией права участников судебного процесса на отвод судьи в гражданском процессе весьма серьезна. По мнению автора, в гражданском процессуальном законодательстве помимо сугубо юридического аспекта появилась (и все больше прогрессирует) политическая

\footnotetext{
${ }^{5}$ Рыжаков А.П., Отвод судьи, секретаря судебного заседания, эксперта, переводчика. Основанный на судебной практике комментарий к ст. 23 АПК РФ.// Система Гарант, 2009 г.
} 


\section{Право и политика $4(160) \cdot 2013$}

составляющая проблемы. Развитие коррупции, и влияния исполнительной власти на судебную в нашей стране, увы, привело к появлению в России двух типов правосудия: законного и политического, о чем свидетельствуют последние несколько лет судебной практики. В случае, когда гражданин остается один на один сполитическом правосудием, при котором решение по его делу вынесено задолго до начала процесса, институт отвода судей становиться едва ли не единственным механизмом, способным вернуть такое правосудие на рельсы закона. Однако реальное право гражданина при той его формулировке, которая содержится в ГПК РФ, является правовой фикцией.

Подводя итоги, автор приходит к выводу о том, что норма, закрепленная в ч.2 ст.20 ГПК РФ в действующей редакции нарушает принципы объективности, независимости и беспристрастности суда, предусмотренные ст. 120 и ч. 3 ст.123 Конституции Российской Федерации.

Право на судебную защиту предполагает наличие конкретных гарантий, которые позволяли бы реализовать его в полном объеме и обеспечить эффективное восстановление в правах посредством правосудия, отвечающего требованиям справедливости. ${ }^{6}$ По мнению автора, требованиям справедливости соответствовал бы иной порядок разрешения заявленного отвода, как это предусмотрено, например, ст. 25 Арбитражного процессуального кодекса, согласно которой отвод судье, рассматривающему дело единолично, рассматривается либо председателем соответствующего арбитражного суда, либо его заместителем, либо председателем судебного состава. Кроме того, данный Кодекс обязывает указанных лиц оформлять решение по поводу заявленного отвода отдельным определением, тогда как ГПК РФ подобной обязанности не предусматривает. Таким образом, нормы АПК РФ явно более близки к реализации тех функций, которые возложены на институт отвода судей.

Выходом из данной ситуации могла бы быть отмена Конституционным Судом РФ некоторых норм ГПК РФ, касающихся отвода судей и явно противоречащих Конституции РФ. В этом случае у правоприменителя появилась бы возможность использовать в гражданском судопроизводстве принцип аналогии закона и применять нормы АПК РФ об отводе, которые, как было сказано, в большей степени соответствуют закону, нежели нормы ГПК РФ.

Однако Конституционный суд РФ полагает «Исходя из конституционных принципов независимости и самостоятельности судебной власти, а также из того обстоятельства, что в демократическом обществе участники судебного разбирательства должны испытывать доверие к суду, которое может быть поставлено под сомнение

${ }^{6}$ Рыжаков А.П., Коментарий к ст. 16 ГПК РФ: основания отвода судьи // Система Гарант, 2009 г. только на основе достоверных и обоснованных доказательств, свидетельствующих об обратном, законодатель в части второй статьи 20 ГПК Российской Федерации установил такой порядок разрешения вопроса об отводе, заявленном судье, рассматривающему дело единолично, который снижает вероятность затягивания рассмотрения дела вследствие недобросовестного заявления кем-либо из лиц, участвующих в деле, необоснованного отвода судье.

Гарантией соблюдения принципа беспристрастности судьи, рассматривающего дело единолично, при разрешении вопроса о заявленном ему отводе является вынесение мотивированного определения, подтверждающего отсутствие обстоятельств, которые позволили бы усомниться в его беспристрастности при рассмотрении данного дела. Кроме того, гарантией являются процедуры проверки вынесенных судебных постановлений вышестоящими судебными инстанциями. При этом вопрос об объективности и беспристрастности состава суда подлежит разрешению в каждом конкретном деле с учетом фактических обстоятельств, установление которых находится в компетенции судов общей юрисдикции. В случае установления обстоятельств, вызывающих сомнение в беспристрастности судей, акты которых отменены судом вышестоящей инстанции, не исключается возможность направления дела на новое рассмотрение в ином составе судей (абзац третий статьи 361 ГПК Российской Федерации) (определения Конституционного Суда Российской Федерации от 8 февраля 2007 года N 325-О-О, от 20 марта 2008 года N 155-О-О, от 15 июля 2008 года N 465-О-О, от 28 мая 2009 года N 617-О-О и др.).»7

Автор не может согласиться с такой позицией толкователя закона.

Конституционный суд РФ,предлагает поставить во главу угла доверие к суду. При таком подходе не было бы нужды в вышестоящих судебных инстанциях и института обжалования судебных актов. Однако этот институт существует и должен существовать в демократическом государстве, следовательно, основываться на одном лишь доверии к суду по меньшей мере неуместно.

Толкователь закона беспокоится о вероятности затягивании процесса вследствие недобросовестного заявления об отводе, при этом фактически предлагает правоприменителю реализовывать свое право на отвод судьи в суде второй и последующих инстанциях. ${ }^{8}$

\footnotetext{
${ }^{7}$ Определение Конституционного Суда РФ от 20 октября 2011 г. N 1364-О-О«Об отказе в принятии к рассмотрению жалоб гражданина Абакумова Евгения Михайловича на нарушение его конституционных прав пунктом 3 части первой статьи 16, частями второй, третьей и четвертой статьи 17 , частью первой статьи 19 и частью первой, абзацем первым части второй статьи 20 Гражданского процессуального кодекса Российской Федерации» //http: // www.ksrf.ru.

${ }^{8}$ Ярков В.В., Арбитражный процесс. М., 1998, С 105.
} 
Стоит отметить, что в соответствии со ст.20 и ст. 331 ГПК РФ жалобы на определение об отводе не подаются, а возражения относительно этих определений могут быть включены в апелляционные жалобы.

При этом последующая проверка решения суда, в том числе на предмет соблюдения принципа объективности и беспристрастности, осуществляемая в вышестоящих судебных инстанциях, не устраняет данную проблему. Конституция РФ закрепляет гарантии соблюдения принципа состязательности и равноправия сторон, предполагающего объективность и беспристрастность суда, а так же принципа независимости на всех стадиях гражданского судопроизводства. Соответственно на каждой стадии должны существовать правовые процессуальные механизмы, обеспечивающие реализацию данных конституционных норм-принципов.

При выявлении небеспристрастности судьи, единолично рассмотревшего дело, только на следующей стадии процесса (после вынесения решения по делу), лицу может быть причинен невосполнимый ущерб. Разрешение гражданских споров отнимает несколько месяцев, а если решение отменяется высшей инстанцией, в том числе по основаниям нарушения принципов независимости, объективности и беспристрастности суда, дело направляется на новое рассмотрение, то процесс разрешения дела затягивается на несколько лет. Кроме того, за это время, например, в результате отказа небеспристрастного судьи в истребовании доказательств они могут быть навсегда утрачены.

При таких обстоятельствах контроль по соблюдению ст. 120 и ч. 3 ст. 123 Конституции РФ в суде первой инстанции судебного разбирательства на следующем этапе судебного производства не является эффективным средством и не гарантирует соблюдения выше указанных конституционных норм.

При таких обстоятельствах правоприменителю остается уповать только на законодательную власть.

Автор полагает, что в Российском праве в первую очередь необходимо закрепить законодательно норму о запрете судье судить себя самого. Такую норму необходимо включить в процессуальные кодексы Российской Федерации, и как следствие привести в соответствие с данной нормой статью 20 ГПК РФ, а именно исключить абзац первый части второй данной статьи.

В идеале нормы АПК РФ, по мнению автора все же не являются совершенными. В частности, было бы разумнее создать специальный коллегиальный орган, на примере скажем института присяжных заседателей. И всякий раз, когда судье заявлен отвод, созывать данный коллегиальный орган.

Такой орган не должен включать в свой состав судей и иных работников данного суда, для целей исключения всякой заинтересованности данного органа в решении вопроса об отводе.

Не секрет, что все судьи, как и прочие работники одного суда лично знакомы друг с другом. Учитывая особенности человеческой психики, человек имеет определенное мнение о каждом своем знакомом и определенное отношение к нему, негативное либо позитивное. Человек не бывает безразличным к своим знакомым тем более к коллегам.

Вопрос об отводе должен разрешаться простым большинством голосов.

Ведь всякое мотивированное заявление об отводе судьи - это поступивший от участника процесса сигнал о том, что данный судья не может больше в силу ст. 3 Закона РФ от 26 июня 1992 г. № 3132-1 отправлять правосудие от имени Российской Федерации.

Именно в таком случае, когда будет работать некий коллегиальный независимый орган, автор полагает, удастся задействовать механизм реализации конституционного права гражданина на судебную защиту его прав и свобод на основе состязательности и равноправия сторон, а также в соответствии с принципами независимости судей.

\section{Библиография:}

1. Добровольский А.А. Исковая форма защиты права. М., 1965, С 180.

2. Багаутдинов Ф.Н.Актуальные проблемы отвода судьи в современных условиях // Журнал российского права № 5, май 2009 г., С 9.

3. Заявление и разрешение повторных отводов суду (судье) на стадии судебного разбирательства // Адвокат, № 10, октябрь 2009 г., С 3.

4. Муромцев С.А., Гражданское право древнего Рима, М., 1883 г. С. 20.

5. Рыжаков А.П., Отвод судьи, секретаря судебного заседания, эксперта, переводчика. Основанный на судебной практике комментарий к ст. 23 АПК РФ.// Система Гарант, 2009 г.

6. Рыжаков А.П., Коментарий к ст. 16 ГПК РФ: основания отвода судьи // Система Гарант, 2009 г.

7. Определение Конституционного Суда РФ от 20 октября 2011 г. N 1364-О-О «Об отказе в принятии к рассмотрению жалоб гражданина Абакумова Евгения Михайловича на нарушение его конституционных прав пунктом 3 части первой статьи 16, частями второй, третьей и четвертой статьи 17, частью первой статьи 19 и частью первой, абзацем первым части второй статьи 20 Гражданского процессуального кодекса Российской Федерации» // http: // www.ksrf.ru. 8. Ярков В.В., Арбитражный процесс. М., 1998, С 105. 


\section{Право и политика 4 (160) • 2013}

\section{References (transliteration):}

1. Dobrovol'skiy A.A. Iskovaya forma zashchity prava. M., 1965, S 180.

2. Bagautdinov F.N. Aktual'nye problem otvoda sud'i v sovremennykh usloviyakh // Zhurna 1rossiyskogo prava № 5, may 2009 g., S 9 .
3. Muromtsev S.A., Grazhdanskoe pravo drevnego Rima, M., 1883 g. S. 20.

4. Ryzhakov A.P., Otvod sud'i, sekretarya sudebnogo zasedaniya, eksperta, perevodchika. Osnovannyy na sudebnoy praktike kommentariy k st. 23 APK RF.// SistemaGarant, 2009 g.

5. Ryzhakov A.P., Komentariy k st. 16 GPK RF: osnovaniya otvoda sud'i // Sistema Garant, 2009 g.

6. Yarkov V.V., Arbitrazhnyy protsess. M., 1998, S 105. 